\title{
STRATEGIES OF CONSTRUCTING A GROUP IDENTITY: THE SECTARIAN COMMUNITY OF THE SUBBOTNIKI IN THE STANIZA NOVOPRIVOLNAIA
}

\section{Sergey Shtyrkov}

\begin{abstract}
This article considers mechanisms of identity construction in one of the present-day communities of Subbotniki in Southern Russia. The study is based on the field recordings made in 2000 among Subbotniki in Stavropolskii krai. The sect of Subbotniki appeared in the 18th century, when some Russian peasants, ancestors of contemporary Subbotniki, repudiated the New Testament as well Christianity and created on the basis of the Old Testament a denomination similar to Judaism. In the 19 th century the members of the sect were displaced from Russia to the Transcaucasian areas where they established a number of mono-confessional villages. In the last decades of the 20th century some Subbotniki came back to Southern Russia and organised their communities in larger poly-confessional villages where they made up a minority. In these new circumstances the Subbotniki recognise their identity as an uncertain one regarding their ethnicity as well as religiosity - they are both Russian and Jewish, neither Russian nor Jewish. To escape this uncertainty Subbotniki try to find "others" who can confirm the particular identity of their group.
\end{abstract}

Keywords: ethnic identity, popular religion, religious identity, Russian traditional sectarians

During the last decades the questions concerning the scholarly concept of "identity" (or, seen from another point of view, the phenomenon of social life) have been eagerly debated within social sciences. As an object of the analysis one often meets such categories of identity like a confessional self-consciousness, local and gender-based self-identification, but the problems of ethnicity and national identity still remain to be the main fields of discussion. For a long time, debates on the nature of ethnicity were carried out between ethnologists and social anthropologists - that is, between the adherents of primordial and instrumental approaches. Supporters of the first group claim that ethnicity is, objectively and steadily, a characteristic of personality: a human being possesses a definite ethnicity (and a feeling of belonging to the group of his/her "own people") because he was born and grown up in a particular ethno-social group. 
From this point of view, a Frenchman proves to be French because his ancestors were French and he was brought up by the French. The adherents of the second group regard ethnicity as a situative self-identification applied by an individual in changing contexts of social intercommunication in order to achieve one's goals. That is, the Frenchman represents himself as a Frenchman in situations, where it is useful for him. Some efforts were made in ethnology to reconcile these two approaches and to unite their main presuppositions into one dialectical model. However, the problems of identity became to be discussed within the studies of another discipline (although related to ethnology). A number of historians, equipped with explanation strategies of social constructivism, began to handle ethno-social units as products of social discursive practices that construct borders between different groups, attributing them a status of possessing specific features and, consequently, an objective existence. By this kind of approach to the problem we have no need to use such characteristics of identity as "innateness" or "arbitrariness". Nations and ethnic groups truly exist and are actually represented in the everyday life of individuals, but they are produced as a result of social projects that are constructed (Anderson 1983); traditions really function like markers of identity, but they are invented (Hobsbawm 1983). The constructivist approach proved its productivity in the studies of identities typical to the "post-traditional", modern European societies. Can it be applied to the analysis of ethnoconfessional identity in "non-imaginary", really existing societies, whose members are acquainted with each other? How does this kind of construction function in those societies, where there is no clearly distinguishable elite, but where the institution of religious leadership does exist? In the present article I am trying to investigate how the social identity is constructed in the sectarian community of Subbotniki, living in one staniza (a Cossack-village) in Stavropolskii krai (Stavropol territory), Northern Caucasus region of Russian Federation. ${ }^{1}$

Thanks to the support from a non-commercial partnership "Peterburgskaia Iudaika" my colleagues Alexandr Lvov, Alexandr Panchenko and I had an opportunity to carry out a short-term field research in one of the communities of the Subbotniki in Northern Caucasus in September 2000. In Stavropolskii krai we worked in one staniza, which is going to be mentioned below as Novoprivolnaia, 
fulfilling the promise we gave to our informants, not to advertise their location. The main purpose of our field trip was to find the representatives of Subbotniki and to establish contact with them, that is, to establish a basis for more detailed studies in the future. We managed to fulfil our goal, and besides we succeeded to get a preliminary overview about the original culture of this group. The result of our work was, among other field materials, 14 hours of tape-recorded interviews with the Subbotniki. The transcriptions of these recordings provided the main source material for this article.

Some words should be added in order to introduce this social group we worked with as well as to accentuate both the restrictedness and specific nature of our material. The Subbotniki of Novoprivolnaia arrived to Northern Caucasus in the 1980s-1990s from two neighbouring Russian villages, Privolnoe ${ }^{2}$ and Navtlug, in Azerbaijan, where they used to live together with the representatives of another group of so-called Judaizing sectarians, the Gers, who, unlike the Subbotniki oriented themselves to the Talmudic Judaism. In these villages the Subbotniki and the Gers constituted a strong ethno-confessional majority. At present the Subbotniki live in a large South-Russian staniza, where they constitute an insignificant confessional minority - approximately around $2 \%$ of the total population. The total number of the Subbotniki in Novoprivolnaia - approximately 300 - should be taken very roughly, as this includes not only the "followers", but also all these people who consider their ancestors to have been Subbotniki and who follow the "Jewish" celebration calendar. Not all of the Subbotniki's neighbours are Orthodox Christians. In the staniza there are also relatively big communities of Molokans, ${ }^{3}$ Baptists, as well as adherents of "Jehova's Witnesses" who are actively doing missionary work. This means that the community of the Subbotniki is not the only religious minority in Novoprivolnaia.

Fortunately we relatively quickly established contact with the spiritual leader of the community, the starshaia 'elder', Maria Azar'evna, ${ }^{4}$ a woman of 65 years (besides she is a daughter of an "elder", who was a respected person in Maria Azar'evna's home village). She rigorously observes the religious prohibitions and prescriptions she is familiar with, controls if possible, the common ritual practice of 
the whole community and, being herself a charismatic person, she also leads the "circle of believers", which consists of a relatively small group of elderly women (there are about 10-15 of them; altogether there are around 40-50 people among the Subbotniki, who correspond to the elder's idea of ritual purity and with whom she is communicating). All interviews, except one rather unimportant, were recorded with Maria Azar'evna and her closer followers. Thus, the survey and all conclusions presented here base on that vibrant, but rather specific material.

The restrictedness of our data is also determined by another factor - our field trip was quite short and for that reason we were not able to carry out any more detailed case study. In other words, we have not too much information about the everyday life of the Subbotniki, especially about the aspects that our informants did not consider to be valuable enough to remember. Therefore it is difficult for me to tell exactly how the interaction between the members of the community and the representatives of other groups functions, insofar as the strangers are for them "the actual others". Without this information it is difficult to understand the peculiarities of the actualisation of self-identification among the Subbotniki of Novoprivolnaia (like probably among any group of social actants). One should remember that identity is constructed and regenerated not only in conversations with researchers (although the researchers may stimulate the reflection on this subject). It includes the choice of a strategy, which is used in everyday social interactions. Yet by all its restrictedness, our material allows us to bring forth the main discursive strategies in the construction of the self-identification by the Subbotniki of Novoprivolnaia.

Subbotniki of Novoprivolnaia are entirely aware of the borders of their own group. In all probability, one of the main features that constitute their identity is to consider themselves to belong to the group of not-beloved and discriminated, potential victims of coming persecutions. Many of the Subbotniki believed that nowadays they are living in hostile surroundings. A certain fear of possible repressions penetrates therefore some of their statements. 
Fragment 1.

Informant 1: Well, but that's right, now you are going to tell here everywhere everything, but after that we won't be left in peace here anymore.

Interviewer: But we won't tell anybody here anything. Informant 1: Well, it's because, you know it by yourself that we went away, but... there we lived more or less normally, there nobody knew anything. But then we came here, and here nobody... likes us.

The peculiarity of their religious instructions and present-day situation make the Subbotniki constantly and even with a certain enthusiasm to construct the system of their self-identification. The Subbotniki loved to talk about this topic, it constantly appears in their discussions and narratives about themselves and the others. In case one tries somehow to make a typology of the identification strategies, it is possible to draw out two main modes of talking and thinking about oneself. We shall call them the positive strategy of constructing identity and, respectively, the negative strategy. These terms are not meant to include any evaluation. The first one signifies the manner of self-identification, which takes place through defining the specificity of one's own group, the stories about its outstanding representatives, in brief, about the way how "we" are. The negative identification strategy is accomplished through direct or indirect interaction between oneself, one's group and the others by defining the characteristics of those "others". Obviously, such kind of distinction of those two strategies is provisional. While talking about ourselves, defining one's own characteristics, we often talk indirectly about the others. But it seems to me that instrumentally this kind of distinction is useful for the analysis of that particular situation.

Let's start with the positive strategy of self-identification. The ethnic component of the identity is rather problematic and, one may say, not yet elaborated by the Subbotniki. In Azerbaijan they called their Russian Orthodox neighbours hohol (a term with a very strong pejorative connotation). Nowadays they sometimes flee to this term as well, although the term "Russians" is also being used for the non-Subbotniki. At the same time the Subbotniki are fully aware of the fact that from a certain point of view they may use this ethnonym 
by themselves as well. But concerning themselves they employ this term, I would say, without any essential knowledge, and mostly in some specific situations. In the following excerpt of the interview the topic of the conversation concerns a specific practice to bring a dying human being from the house into the yard. ${ }^{5}$

Fragment 2.

Informant 1: [---] They ask. I do not tell them, that I am a Subbotnik, that I have a kind of faith. I say: Russian. And that's all. And why should I explain them.

Informant 2: Because not everybody understands.

Informant 1: Not everybody. That's my talk...why didn't he lay so? Normally you put the dead like this, but by us he laid that way. Why? Why there is no cross? I say: he wasn't baptized. Well, I... I do not hide that I'm not baptized. I say: I am not baptized. Then they again say... one can always make the sign of the cross! I say: no. - But how are you going to die? I say: where God leads me there I'll go. And that's it. Why should I tell him? [---] Why on earth should I tell this? For what reason? I have my own faith and that's all.

As we see, while talking to her neighbours, the informant called herself Russian, although not a baptised one. But this "Russian" sounds somehow ambiguously, like some kind of a half-truth. It's not surprising that in other communicational contexts the Russians are mentioned as the representatives of the group of strangers, whom one attributes very negative characteristics (see below). Hurrying on ahead, I note that in the afore-mentioned statements appear the impersonal "they", who in spite of their impersonality or thanks to this, appear for the Subbotniki as significant "strangers".

In another story, in a short aetiological legend, a Subbotnitsa (i.e. a female member of the group of Subbotniki), answering to our relatively directly formulated question, handles the problem of "Russianness" in a different way.

Fragment 3.

Interviewer: But how do you feel who you are? Jews or Russians or who?

Informant 3: We are Russians. We are probably the strangers. ${ }^{6}$ Once God led... Probably in this time, when God led out from 
Egypt, there were Russians as well, right? And who wanted, went with them. So we descend - from them. We aren't Jews, we are Russians.

One must say that in this case the provocation was not completely from our side. The question of the interviewer was just a short comment in the discussion started by the Subbotniki themselves. "We aren't Jews" - this is an answer to everyone who calls them (that is, oneself) a Jew. ${ }^{7}$

The most definite and clear feature, constituting the identity of the Subbotniki, is the religion. Calling themselves Subbotniki, Russians of the Mosaic Law or people of the Mosaic Law, they relate themselves to the group, professing an absolutely determined religion, different from Orthodoxy, Islam, the faith of the Molokans, etc., in a certain way also different from Talmudic Judaism. The Subbotniki are proud of their religion. According to their statements, nothing can characterize a human being better than his/her readiness to follow rigidly and unselfishly the prohibitions and orders, regardless of physical illness and possible economic loss (it appears, in particular, concerning the prohibitions connected with Saturdays, when the orders of the Law, concerning the day of rest, are turned into some kind of an ascetic practice). ${ }^{8}$

Adherence to the Law is often a subject of conversations and shapes the pathos of historical legends.

Fragment 4.

Interviewer: Please tell me, how did the Subbotniki come to Transcaucasia, to Azerbaijan?

Informant 4: Well, I even do not know exactly, how they got there. They went... who is elder, he knows, I also heard something, but how... Our ancestors went there, our ancestors!

Interviewer: But what was told? Did the old men tell something? Informant 4: Well, they told, that too, how they were here and accepted this faith. And had driven there. Because they lived here with this faith, but... somehow Ekatherina [empress Catherine the Grate], in a way, made it obligatory to eat this pork. You see, I do not keep any pigs here either... So, well, so we used to live. 
It is pretty characteristic that in their discussions the Subbotniki presume that God's attention is turned directly to them, and the way how accurately they follow the Law. Typological parallels are here so evident, that I will not dwell upon them. ${ }^{9}$ But I would like to draw attention upon the modes, how it is reflected in the imaginations about the reasons and the nature of their migration.

Fragment 5.

Interviewer: But still, why did you left Privolnoe? You obviously lived well there...

Informant 5: Well, it is written in the Law... It is clearly written in the Law, in the Bible. Oh! - When the people fall in sin, I'll scatter them all over the world. All over the wide world. As peas in a sieve - so is written there. - I'll scatter... everybody. Nobody is going to pursue them, to chase them... ${ }^{10}$ A leaf, it says, is whispering - but they are going to be afraid! They will flee! - Well, the Azerbaijanis started to persecute us. Well, they did not directly drive us away, but...

As we see, what is written in the Law is obviously valid only for the inhabitants of Privolnoe and Navtlug, that is, for them whom the Law is given to.

Not too obvious, but in the same time a very distinguishing aspect of Subbotniki's identity is their common origin; that is, local identity, well-known to all researchers of Christian communities. True enough, in our case it is projected into the past. This aspect of the identity determines in many ways the behaviour of those people with whom we were working with. On one hand, all emigrants who descend from Privolnoe, support each other actively, they are "the own ones" to each other (as they are "the own ones" also to the resettlers from this village, living in other regions). On the other hand, they do not make any efforts in order to come into contact with the North-Caucasian fellow believers, although the rumours about their existence actively circulate among the former inhabitants of Privolnoe. ${ }^{11}$

At last one should mention one more aspect of the positive strategy of self-identification by the Subbotniki of Novoprivolnaia, which I would interpret as the most actual one for their group: they feel themselves as migrants. In this sense they also re-interpret the 
biblical term "strangers" that is used to signify their present state of existence. The Subbotniki are aware of their similarity to other migrants - to the representatives of small religious groups. They tell each other alarming news, for example, how somewhere the Molokans, who also resettled from Transcaucasia, were persecuted by the local church officials. Such stories force the members of the community to feel even more strongly the borders of their own group; they provoke conspiratorial and escapist moods.

The story about the persecuted Molokans (towards whom, by the way, the majority of the people we talked to did not felt any sympathy) demonstrates, how close to each other those two above-mentioned strategies of constituting the identity are in the concrete discursive context - this, what did not happen to us, has a certain relation also to ourselves. But in its most explicit form the negative identification strategy appears in the direct relation of one's own group (and its single representatives) to the "strangers". ${ }^{12}$ Not a single system of self-identification can exist without any distinct "strangers". ${ }^{13}$ The "strangers" are not always negatively represented. Therefore, for instance the Azerbaijanis, the former neighbours, are mostly perceived positively. This attitude is certainly supported by the nostalgia for the homeland left behind, the lost paradise, where the spirit of friendship and openness ruled, what the Subbotniki do not find in Russia.

Fragment 6.

Interviewer: But there [in Privolnoe] it was, of course, better to live, right?

Informant 1: Oh yes! No need even to talk about this! The Jews with the Subbotniki... these are, like, Azerbaijanis - we hold on to the same faith. Hold on to the same faith. One is not allowed to eat pork. There, for example, if we celebrate Saturday, they know already - oh, they even never say us anything there. But here already - we all are afraid. Already all, everybody already hides his belief. Everybody hides.

The ideas about the Azerbaijanis (it must be mentioned that the figure of a Moslem is missing on Subbotniki's picture of the social field) are represented in the terms of blood relationship. 
Fragment 7.

[The discussion concerns the possibility to contract a marriage with the representatives of other groups.]

Informant 3: The Azerbaijanis are according to the Law our cousins, because they descend from Abraham.

Informant 4: They are circumcised, as we are. Anyway, it is written by Abraham: "It is allowed to go out, it is allowed to marry".

But in addition to the Azerbaijanis the Subbotniki still have other brothers - the Jews - although the attitude towards them is rather complicated. In this regard our effort to get in touch with our informants was quite significant. Right away, when we, after some searching, had found Subbotniki in Novoprivolnaia, they defined us as Jews, which probably made the contact between us possible at all (considering the conspiratorial moods of our interlocutors), but it determined a specific nature of our intercommunication, in many points different from the role pattern (interviewer vs. informant) we were used to. In the beginning we were the ones who were asked questions. In the following fragment of an interview made with the "elder" Maria Azar'evna the discussion is about the ritual impurity of a woman during the menstruation and we talk mainly about the custom being widely spread among the Subbotniki, to settle a woman for this period in a special "impure" corner of the house - this must guarantee, that other living rooms, objects and people will not be polluted through contact with her.

Fragment 8.

Informant 5: Let's take a woman. She has her period. So, how do yours think about this? She is impure, right?

Interviewer: Yes.

Informant 5: Does she sit separately?

Interviewer: $N o$.

Informant 5: How can it be?

Interviewer: But with you she sits separately, right?

Informant 5: Yes. But why doesn't she sit with you like this? Moreover, you are... like... the real ones, the ancient ones. You are Jews. [---] You know all this, friends. But why does she with you... go together, do everything? She doesn't sit separately?

Interviewer: Well, with us it is that way... these are our customs. 
Informant 5: [Smiles] Listen, Marusia! They do not do it that way.

Informant 3: They do it differently.

Informant 5: I know, that is why I ask. Differently. But why differently?

Interviewer: Well, I guess, you know, you probably met Jews before already, right? You lived together with Jews in Privolnoe. You certainly saw that they have the same customs...

Informant 5: But who gave them right to do this?! Are they right?! How can it be... they do not sit - are they right?! They were justified? But in the Law... Do you read the Law? [---] You do. But what is written in the Law? If the woman is impure... Yes? She must sit seven days in order to get purified. Isn't it written like that? But why doesn't she sit then?

Interviewer: Well, one can understand it in different ways... Informant 5: But because it is difficult! To sit - it is difficult. Children - small ones - ask for food, ask for drink... Look, I had eight children [---]. One must prepare, make food, cook, must... That means, I'll go, I won't sit-of course, for me it is eas... easy. But if I am going to sit, then the children: Mama, I want to eat! Then... I should go and milk a cow [---] Of course it would be much easier, if I could do this by myself. [---] And what else is also written in the Law? You know it very well! How is it? Talmud was put together. Yes? And because of this you do not sit. Do not sit. That's right? But the Law was written... well-it was written by God, the Law. But this Talmud - this was already later... put together... ten people gathered together and made it. In general... they just wrote it. That's it. Thus, it became easier.

As it appears from the text given above, this part of the interview represents the controversy between the teacher, the "elder" of the Subbotniki with the Jews, representatives of the close religious group, who in spite of the fact that the Law was given precisely to them did not keep it in purity, but distorted many orders because of their human weakness. ${ }^{14}$ From the point of view of religious morality, according to which the obeying of prohibitions and orders is inevitable condition for faith, such kind of behaviour appears as condemnable. Our visit offered to the "elder" a wonderful possibility to make the Jews answer and to demonstrate the superiority of Subbotniki over the Jews. Still it did not exclude the possibility for 
a dialogue. Apparently Maria Azar'evna's questions were not rhetorical at all (regardless of the characteristic commentary: "I know, that is why I ask"). After some doubting we tried to explain that after destruction of the Temple the fulfilling of all prescriptions of the Law (especially those concerning the ritual purity) became impossible, but Talmud was composed in order to organize the religious life of the Jews under new circumstances. From this the listeners drew a conclusion that the ancestors of the Subbotniki had obviously left Israel before these events took place and therefore they could keep the whole complex of prohibitions and prescriptions intact. The Jews turned from the malevolent apostates into the victims of circumstances, proving thereby the high status of the ancient faith of the Subbotniki. An interesting detail should be mentioned here. After our explanations Maria Azar'evna sang a psalm "Behold, how good and pleasant it is when brothers dwell in unity!" (Ps. No. 132) with the refrain "Soon, soon we depart/ soon, soon we wait/ the glory of Israel". We (as Jews) were acknowledged as brothers, sharing with the Subbotniki the hope to come (or to turn back?) to the promised land. In this way the Jews as "close strangers" proved to be important in the construction of the identity of the Subbotniki. The Jews function as some kind of an expertise, as a proof for the "genuineness" of Subbotniki's faith, thereby they keep the status of "apostates" - they are at the same time higher and lower than their opponents. We can prove this conclusion with a different kind of evidence. Below follows a conversation, which describes how a pious Subbotnitsa meets the Jews.

Fragment 9.

[The discussion is about purification after the ending of the menstruation.]

Interviewer: But is it generally needed to control [if the menstruation is over] or how?

Informant 7: Well, of course! Of course! Purity is purity! We had one elderly woman in Privolnoe. She was an orphan. She did not have anybody. And then came one rabbi. And then her... he was told that, well, that she is an orphan, but she is, say, good, say, friendly, a good girl.

Informant 6: But who is this? 
Informant 7: She was... Man'nka Verbilina's mother-in-law. [She explains where this family lived in Privolnoe.] Esvir.. aunt Esvir is her... mother-in-law. Esvir - this is mother-in-law. So. Came rabbi, took her. Took and drove away. Drove away. Then I was free. Earlier one went here and there. The borders were not there. And he took her there, to this... Jerusalem. But he arrived, his wife gave birth to twins. She would have had it difficult [to nurse them]. So he wanted her like a baby-sitter and took her. He took her as a baby-sitter; she looked after the children there. But then time went and... she got her period. But she had been taught. (If I would be used to... Well, I married one of the Gers, but she, the mother-in-law, did not want to. By these... by the Gers-they do not have that. Yes.) But she... So she got her period. She said to the housewife: "I won't do anything". - "Why this?" - "My period has started". She says: "And so what?" She says: "No, I won't sin. I," - she says, - "since my childhood..." (But she was already eighteen years old.) "I," - she says, - "since my childhood I suffered because of this. But now,"-she says, - "no, I won't". So they put her into the corner. They give her food; they give her everything. Then came the Jewish women and looked at this: "How is this?! But if suddenly our husbands will come and see her like this. Then they'll get to know this and what a shame on us!" What a shame [not to keep religious rules on female impurity]! Then they went to the most important rabbi and said: "Come to this house. The breaking of law, you'll see, is taking place there”. Then he came, looked at this. Asked everything. Asked her, asked the housewives, the men, asked everybody. She told everything. "By us" - she says, - "in Privolnoe, we do like that. When [the period] is over, then it is all right". He listened to everything and said: "You are a good girl. Good girl. But by us," - he says, "ours," - he says, - "women eat," - he says, - "all with this execration. So. And do they purify themselves then! They just wash themselves and consider that they are purified after this! Only to wash - and she is clean!" ${ }^{15}$ He says: "You are a good one. You do like the Law tells". But the Jews, - they did not accept this [position]. But why, I do not know.

The "lawless" Jewish women provoke a scandal, fearing that their husbands, while seeing how the Law is obeyed properly, notice that their wives are not following the orders of purity. In this story they 
play a role of apostatic Jews. But another Jew, "the most important rabbi" declares that namely Subbotniki do everything "according to the Law", not the Jews (resp. Jewish women). It is distinguishing how a direct contact, a dialogue between the Subbotniki and the Jews, takes place in the context of conversation between the gathered Jews and within the framework of a narrative. ${ }^{16}$ The Jews do not remain members of the "hardly imaginable society" as in the expressions of the Subbotniki they are absolutely real.

Nevertheless, this should not be said about the other "close strangers". As was already mentioned above, the Subbotniki sometimes define themselves as Russians. But it can happen that in the context of the same conversation an interesting switching of the identity may take place. The informants tell about Russians as about representatives of a group being strange to them and famous for its dishonourableness; after some time, however, they identify themselves (although with some reservations) with the Russians, or better to say, they flee to this term in order to define their own identity. Let's have a look at the following example - I already cited some fragments of the transcription of this interview (see the fragments No. 7 and No. 3), now I am going to present a somewhat more extensive passage.

Fragment 10.

[The conversation concerns the possibility to marry representatives of other groups.]

Informant 3: The Azerbaijanis are according to the Law our cousins, because they descend from Abraham.

Informant 6: They are circumcised, as we are. Anyway, it is written by Abraham: "It is allowed to go out, it is allowed to marry". Informant 3: But to marry a Russian - well, it is like day and night. He is like a dog. As with a dog, so it is with a hohol - it is all the same.

[The conversation continues with the discussion whom else and why one is not allowed to marry; in this context the interviewers turn back to the question about the Russians.]

Interviewer: But are the Russians accursed too, or is it just because they are impure?

Informant 3: No. [---] Russians - they are not circumcised. They did not obey [the norms]. They did not start to believe in the 
Law. [---] But there is written. Well... One says, that - their ears, they do not listen. Let's take these icons - how they are done: [they are of] wood, stone, gold, silver. All kind of materials. And the main thing - how they have been painted. The wooden icons - he cut a good tree, made an icon out of this. A God. After that he heated an oven with the wood from this tree, baked bread, cooked, ate. But how can it be: made a God by himself and from God these [pieces]... burned..

Thereby after some minutes the same informant, representing the Russians as worshippers of the idols ("gods", in this case - the icons), apostates of the Law, that is, as perfect non-Subbotniki, answered to our proposal to "choose an identity" (But how do you feel who you are? Jews or Russians or who?"): "We are Russians" (see fragment No. 3). Obviously, the proposed choice indicates rather a wish to dissimilate the Subbotniki and the Jews (the Gers). But here something else is significant: the negative associations, connected with the ethno-confessional group "Russians", ceased to be topical in this context.

Let us take a notice of the following peculiarities of the conversation given above. As the discussion concerns marital preferences the informants themselves suggest the term "Russians" (and its contextual synonym hohol) to signify "the ideal strangers". "Russians" are thereby characterized in sufficiently general terms of apostasy of the Law, idolatry - in general terms in this sense that the nature of these strangers must not be proved by telling any stories taken from the real life, and on the level of identification discourse no dialogue between the Subbotniki and the Russians is presupposed.

The term "Russians", being used by the Subbotniki for signifying themselves (see the fragment No. 2), actualizes another aspect of its semantics. To represent oneself as Russian means in this context, to tell that you are "like everybody else". The Subbotniki make use of this in the situation of their contact with "them" - that is with the members of the "imagined community", which members are, for instance, the well-intentioned neighbouring woman, who tried to convince the "non-baptized" Subbotnitsa to let herself be baptized; the village folk from their village, who, as some of the Subbotniki think, keep a watch on every single footstep they make; 
the people from the television and the representatives of the local government. This group has one very clear characteristic - "they" do not love the Subbotniki or the Jews (but consequently, also the Subbotniki). Maria Azar'evna sees the situation in the following way:

Fragment 11.

Informant 5: Well, next to us lives the investigating judge. Tomorrow he's going to draw me in some kind of affair... You're going to loose your place... Because of this one must be afraid of. But when you came here to me - did you ask my address from anybody? From nobody?

[Trying to calm down our collocutor, we explain that we had gone to her avoiding the local authorities.]

Informant 5: One could have said that the relatives arrived [---]. But perhaps you said: look, we came on this business. Here I'll be guilty right away and that's all.

Interviewer: But do you know that nowadays it is not allowed to persecute for this? Because everybody has his own religion and everybody has right...

Informant 5: I agree with you. But they are day and night... well, I am here, but he goes around in his yard, this investigating judge. I only hear: Oh, they are Jews! Jews, they say! The Jews! And everywhere, to everybody! And overall... in "Vremia" [a Russian newscast]. I watch a television, I lie, there are all kind of... improprieties [laughs]. But when "Vremia", then... There as well they say, for example: "Jews are guilty! They are sly, they are everywhere in power..." They say so, they say so... in the television, and overall... They say: really like... they are sly, they are clever... The clever Jews are like this. So it is, and they say... they hate... they do not want to. [Whispering.] They do not want us! And... because of this we are afraid of them!

As we see, the anti-Semitic discourse is well known to the leader of the Subbotniki of Novoprivolnaia (although it is unlikely the discourse in the Russian News Broadcast Company). Thereby she projects the comments about the Jews (or what in her opinion is said about them) directly to her own group, which is in danger "they" are always nearby (in the neighbouring village) and always ready for acting. In Maria Azar'evna's opinion, shared by many elderly Subbotnitsas, only the fulfilling of the conspiratorial rules helps 
to avoid the punishment. ${ }^{17}$ The feeling of danger, originating from "them", as it often happens in similar situations, consolidates the group of religious activists in the community of Subbotniki and appears to be a specific guarantee for its preservation. ${ }^{18}$

Concluding the discussion about the negative strategies of constructing the identity by the Subbotniki of Novoprivolnaia, one must point at one more remarkable fact. Careful conspiring leads some of them to look at the situation through the eyes of their not-well-wishing neighbours (i.e. through "their" eyes). Probably therefore the women of Subbotniki's group discussed during our conversations about the existence of horrible sects, secretly fulfilling their rituals. Everybody, who took part in this conversation, sharply condemned the existence of such sects.

To sum up, I will shortly try to describe the main figures, characteristic to the identity of the Subbotniki in Novoprivolnaia.

Obviously the religious aspect is dominating in the identity of the Subbotniki: the Subbotniki understand "themselves", and similarily also many other "close strangers" - Jews, Azerbaijanis, Russians (the Orthodox) - primarily as religious groups. Some of the specific features of the self-consciousness of the community discussed above can be explained by the relatively recent migration, supplemented by the fear that people would see in them not just the resettlersstrangers, but also the ones with a different faith - the Jews. Therefore the Subbotniki tend to see themselves as potential victims of persecution from the almighty "them". This fear consolidates the community and in my opinion stimulates the preservation of retrospective local identity (the members of the group are united by the fact that they themselves or their parents descend from the same region, from the same community). Thereby the ethno-national aspect of self-consciousness remains non-elaborated among the Subbotniki (or not-acquired). The ethnical terms "Russians" and "Jews" are actualised rarely and are thus used only in special situations for signifying the own group (and oneself personally).

I suppose that in the quickly changing world the children and grandchildren of our informants, even if they do not give up the faith of their ancestors, are going to build their identity on different principles. 


\section{Comments}

${ }^{1}$ Subbotniki (from subbota - Saturday) are members of a so-called Russian traditional sect. This religious movement appeared in the middle of the 18th century. Subbotniki reject the Christian doctrine. They do not recognize New Testament as Holy Writ and base their religious beliefs and practices on their interpretation of Old Testament, especially Pentateuch. Before the 1917 revolution there were about 40 thousand Subbotniki in the Russian Empire. For brief description of the peculiarities of the religious world view and the ritual practices of Subbotniki see Panchenko 2003.

${ }^{2}$ More about the sectarian communities in these villages look in Dymshiz 1999.

${ }^{3}$ Molokane are members of another Russian traditional sect. The sect appeared in the middle of the 18th century. Molokane are Christians, but they reject the authority of the Orthodox church and such religious practices as the cult of saints, icon veneration, etc. Some scholars named them "Russian folk Protestants".

${ }^{4}$ The names of the informants have been changed.

${ }^{5}$ According to the ideas of the Subbotniki, any contact with the dead body can harm the ritual purity of a man as it makes him "spiritless". It also concerns the things. If the death comes to a house, it evokes a necessity to accomplish a purifying ritual of rooms, which is pretty complicated and expensive for a family. Therefore, when one can notice the signs of the approaching death, the dying person is brought out into the yard.

${ }^{6}$ Our informant used here a term from the Pentateuch, where it signifies a non-Jew, who has accepted the laws of Judaism and has become an affiliate of Israel.

7 The Subbotniki used the term "Jew" to denote themselves relatively seldom and mostly in exceptional situations. For example, to the question of his non-Subbotnik friends about his confession a young Subbotnik answered that he was a Jew. When we asked, why he answered that way as he knew well that Subbotniki were not Jews at all, he explained: "Otherwise one must explain them [i.e. friends] for a long time".

${ }^{8}$ I will give here one more distinctive example. We were present as one of the Subbotniki told to her fellows about the disagreement she had had with her daughter and her husband, who wanted to breed a pig, in order to sell it. The storyteller threatened the young couple with parental damnation, if they do not agree to give up their intention. She claimed that this 
threat made them to change their mind. Listeners warmly approved the firm principles of the heroine.

${ }^{9}$ Obviously any religious group with strong eschatological feelings and members who believe themselves to be the "chosen people", would possess this feature.

${ }^{10}$ Leviticus 26: 17.

${ }^{11}$ A special marker of the belonging to the same group is by the Subbotniki of Novoprivolnaia the "remembering" of the common Azerbaijani past through humorous exchange of commentaries in Azerbaijani language that they generally cannot speak.

${ }^{12}$ Fredrik Barth (and many others after him) noticed appropriately that without "strangers" a social (for Barth - ethnical) group cannot exist as a group (Barth 1969).

${ }^{13}$ There exists a great amount of literature on the role of the notion "strangers" in the construction of identity. One of the last works in this field, see Triandafyllidou 1998.

${ }^{14}$ It is pretty unlikely that Maria Azar'evna ever had an opportunity to argue with religious Jews. But with the representatives of the Talmudic Judaism, and namely with the Gers, she most probably had had some disputes about the questions of faith, or she was at least acquainted with the principles of the "antitalmudic" argumentation, as she knew this from the representatives of the elder generation of her family. Precisely this kind of experience foregrounds the "elaborateness" of strategies of rhetorical polemics, close to the rhetoric of the sectarian polemists against Orthodox missionaries of the 19th century (see Lvov, in print).

${ }^{15}$ Here a Jewish custom is mentioned according to which a woman plunges after her period into the mikvah. In Judaism, mikvah refers to a small indoor pool usually found on the premises of synagogues or in separate facilities nearby, and the spiritual rituals associated with it. The only aspects of ritual purity to be maintained via the mikvah are concerned the menstruant woman, the woman who recently gave birth, etc.

16 The close relationship between the narrative about the Jews and polemics with them is depicted in the following episode. During a group interview one Subbotnitsa told us how she once, when she was still young, had visited one acquainted Jewish woman on Saturday. There she had seen a teakettle standing on the fire - a direct proof of violation of Saturday's prohibitions. When the Jewish woman then offered her some hot tea, the "heroine" of our story (she is also the story-teller) refused resolutely, dem- 
onstrating that way the firmness of her religious convictions. The question "How can this be allowed?", which was referred to us (as "Jews" being present), one must have understood as a claim, to condemn the behaviour of the kinsmen. We did not find it necessary to disappoint the expectations of all the people being present.

${ }^{17}$ Here I intentionally do not dwell on the analysis of the relationship between the preservation of such fears and the function of the religious leader of the community.

${ }^{18}$ One must note that the Subbotniki could not tell us a single story about the cases how they have been persecuted. Besides this, these Subbotniki who have stressed the need for the conspiring activities, disregard the communicative activity of their children and grandchildren who do not hide their confessional belonging from the same-aged acquaintances.

\section{References}

Anderson, Benedict 1983. Imagined Communities: Reflection on the Origin and Spread of Nationalism. London: Verso.

Barth, Fredrik 1969. Introduction. Ethnic Groups and Boundaries: The Social Organisation of Cultural Difference. Ed. Fredrik Barth. London: George Allen \& Unwin, pp. 9-38.

Dymshiz, Valeriy. 1999. Etnograficheskoe opisanie sela Privolnoe. Materialy Shestoi Ezhegodnoi Mezhdunarodnoi Mezhdistsiplinarnoi konferentsii po judaike. Part 2. Moskva: Sefer, pp. 71-85.

Hobsbawm, Eric 1983. Introduction: Inventing Traditions. The Invention of Tradition. E. Hobsbawm \& T. Ranger (Eds.). Cambridge: Cambridge University Press, pp. 1-14.

Lvov, Aleksadr L. (in print). Chtenie Biblii i ritorika nachetnikov (po materialam pravoslavnykh missionerov kontsa XIX - nachala XX v.). Issledovania po narodnoi religioznosti. Materialy nauchnoi konferentsii. Sankt-Peterburg.

Panchenko, Aleksandr. A. 2003. Subbotniki i ikh sny. Svoi ili chuzhoi? Evrei i slaviane glazami drug druga. Moskva: Sefer 2003, pp. 288-319

Triandafyllidou, Anna 1998. National Identity and the 'Other'. Ethnic and Racial Studies. Vol. 21. No. 4, pp. 593-612. 